\title{
Talent Management for Organisational Performance Development in Bangladesh Private Industry Context
}

\author{
Md Asadul Islam \\ Faculty of Economics and Management \\ Universiti Putra Malaysia (UPM), Malaysia \\ Amer Hamzah Jantan, PhD (Corresponding Author) \\ Faculty of Economics and Management \\ Universiti Putra Malaysia (UPM), Malaysia \\ Md Adnan Rahman \\ Putra Business School \\ Universiti Putra Malaysia (UPM), Malaysia
}

Abu Bakar Abdul Hamid, PhD

Putra Business School

Universiti Putra Malaysia (UPM), Malaysia

Fariha Binte Mahmud

Jahangirnagar University (JU), Bangladesh

Ashikul Hoque

Putra Business School

Universiti Putra Malaysia (UPM), Malaysia

Received: Aug. 29, 2018 Accepted: Sep. 16, 2018 Online published: Sep. 17, 2018

doi:10.5296/ijhrs.v8i4.13665 URL: https://doi.org/10.5296/ijhrs.v8i4.13665 


\section{Abstract}

The primary objective of this study is to identify the challenges of talent management (TM) practices within private organisations in Bangladesh. This explorative study used unstructured interview methods for the data collection. This study conducted only ten interviews including seven experts from the private sector of Bangladesh and three scholars from reputed universities of the country. After a sequential analysis of all the transcripts of the interviews, four main areas have been identified as the main challenges for talent management practices and performance development in Bangladeshi private organisations: (1) high expenditure; (2) lack of government support; (3) poor awareness; and (4) very few skilled trainers. This study includes a discussion on how TM can be applied in Bangladesh for the development of organisational performance.

Keywords: talent management, private organisations, Bangladesh, government, trainer

\section{Introduction}

In this modern and competitive world, companies generally view employees as the core assets and often rely on their input in the decision-making process for organisational expansion, new product development, competition management and so on. Researchers have identified that if the employees do not have updated knowledge and practical experience they cannot make the desired contribution to the organisation. In this regard, talent management is considered as the most effective process to ensure every employee is capable of performing according to the industry standards and organisational expectations (Heinen and O'Neil, 2004; Nilsson \& Ellström, 2012; Thunnissen, Boselie, \& Fruytier, 2013; Khilji, Tarique \& Schuler, 2015; and Glaister, Karacay, Demirbag, \& Tatoglu, 2018).

Talent management facilitates in attracting talented employees, motivating them, increasing and improving employee performance, engaging employees, retaining high-quality talented employees, and ensuring continued coverage of critical roles to maintain client and employee satisfaction (Christensen Hughes, \& Rog, 2008; Vaiman, Scullion, \& Collings, 2012; Llamas, 2018; and Glaister et al., 2018). According to Vaiman et al., (2012), talent management is not a simple process to implement in organisations because many managers in different countries mistakenly use this as human resource management (HRM). However, both TM and HRM are totally different; therefore, it is very important for the companies to understand what talent management is and how it can be implemented so that its benefits can be enjoyed for the continuous development of the organisation in this competitive business world.

Numerous studies have been carried out in different industries across various countries, both developed and emerging, relating to talent management practices (Heinen and O'Neil, 2004; Christensen Hughes, \& Rog, 2008; Vaiman et al., 2012; Al Ariss, Cascio, \& Paauwe, 2014; and Sheehan, Grant, \& Garavan, 2018). However, many of them have been conducted in relation to the developing country context, specifically relating to Bangladesh, which is one of the fastest growing economies in South Asia.

The country has been one of the key destinations for foreign companies that need to produce goods, such as readymade garments, leather products, shipbuilding and so on (Kantar 
Worldpanel, 2018; Trade Economics, 2018) as a result of the cheaper labour and production costs (Haq, 2018). The level of foreign direct investment (FDI) was increased from USD 1285 million in 2016 to USD 1706 million in 2017 (Trade Economics, 2018; Euro Monitor, 2018). The Bangladeshi government's projected FDI by 2020 is USD 1900 million (Trade Economics, 2018). Furthermore, the local buying power has also been increasing every year along with the increase in GDP. Therefore, consumption by the local people of Bangladesh will be increased in the near future which will push the respective government to develop its human resources so that growing demands can be met to enable sustainable development. In this regard, TM practices can be effective; therefore, this study aims to identify the current stance of Bangladeshi organisations relating to talent management, the challenges of applying it and how the TM practices can be applied. The outcome of the study can also be used as the foundation for future research works in other developing countries. The field study consisted of ten semi-structured interviews with ten main questions concerning talent management and its perspective in Bangladeshi private organisations with seven employees from renowned companies and three scholars from renowned universities within Bangladesh.

\section{Literature Review}

\subsection{Talent Management and Its Significance}

Talent management (TM) has been defined in many ways by scholars and it is not only defined as a term but also as an organisational strategy (Collings, 2014; Tafti et al., 2017; and Vaiman, Sparrow, Schuler, \& Collings, 2018). TM is the organisational commitment to recruit, hire, retain and develop the most talented and superior employees available in the job market (Collings, Scullion \& Caligiuri, 2018). In addition, TM is also a business strategy which is applied in organisations to enable them to attract and retain highly talented and skilled employees (Guthridge, Komm, and Lawson, 2008).

Organisations have been facing various fluctuating internal and external challenges; one example is the way in which working procedures inside of an organisation have been changing due to technological integration, while on the outside, new offers, products and services of competitors also compel organisations to bring about changes in the working processes (Starbuck, 2017; Collings et al, 2018). As a result, critical roles arise continuously resulting in the companies having to attract talented employees or improve the skills of their existing employees so that those roles can be performed appropriately and responsively to situational demands both internally and externally. In this regard, if the organisations apply the talent management strategies they can attract and retain the required employees (Guthridge et al, 2008; Sidani \& Al Ariss, 2014; Brewster, Cerdin, \& Sharma, 2017).

In recruitment, TM facilitates to identify 'good fit' employees for the team in question with the ability to retain them, rather than making spare of the moment decisions which does not always work for the organisational strategy (Schuler et al, 2011; Brester et al., 2017). In this regard, TM ensures that top talented individuals within the organisations remain with the organisation longer because it impacts them as well with greater benefits (Festing \& Schäfer, 2014; Sheehan et al., 2018). This is also supported by the findings of Heinrich (2017) and Oladapo (2014) in that TM contributes to ensuring there are enough employees with relevant 
skills and experience within the organisations. According to De Gieter \& Hofmans (2015), in this current era employees in an organisation do not only expect salaries anymore but higher integrated benefits matched with the organisations. In this regard, nurturing the existing talents can facilitate in both improving the performance and attitudes of the employees because their own competencies have been developing, which is necessary for their future careers (Wilder, Collier \& Barnes, 2014; Vaiman et al., 2018). Consequentially, the employees tend to remain with the organisations for the longer term.

Talent managements aims to ensure that employees are engaged because, as a similar concern to the human resource department, it concentrates on how the employees can be engaged and motivated, increasing their skills and abilities so that they can work towards organisational goals (Erickson, 2008; Cappelli, 2008; and Wilder et al., 2014). Thus, individuals, teams and overall organisational performance is accelerated in a positive way. In addition, TM integrates organisational objectives with the employees' knowledge and skills that facilitates employees in serving clients or customers and producing good quality products and services for organisational and stakeholder satisfaction (Al Ariss et al., 2014; Khilji et al., 2015; and Collings et al., 2018).

\subsection{Requirements of TM and Challenges in Its Application}

Fulfilling the needs of the company's organic growth (increasing output and sales) and inorganic growth (mergers and takeovers) is crucial to remain competitive in their respective industries or sectors (Erickson, 2008; Bahadir, Bharadwaj, \& Parzen, 2009; and Khilji et al., 2015). According to Erickson (2008) and Tafti, Mahmoudsalehi, \& Amiri (2017), to retain greater talent management the organisations should create a valued proposition with the right management team that appeals to multiple generations according to their needs, assumptions and preferences. In this regard, creating a separate talent management team with technological integration can be effective rather than traditional human resource management or planning - TM will work solely for attracting, hiring, retaining and developing talented employees (Iles, Chuai, \& Preece, 2010; Tafti et al., 2017, Collings et al., 2018). However, creating a separate TM system from the holistic HRM within an organisation is not an easy task because of lack of awareness, lack of leadership, the training skills of managers or leaders in the organisations and the organisational culture (Tafti et al, 2017).

For successful TM, transformation of the knowledge and relationships is another imperative requirement because the looming retirement issue for the bigger proportion of skilled employees with tacit knowledge creates challenges for the organisations (Erickson, 2008; Barkhuizen, Mogwere, \& Schutte, 2014). In this regard, regular training by the superiors or experienced employees can contribute to developing existing talented employees to take the vacant positions (Nilsson \& Ellström, 2012; Sidani \& Al Ariss, 2014). However, arranging for training in the organisations and sending employees to the external training institutes requires substantial expenditure (Tafti et al., 2017; Collings et al., 2018; Vaiman et al., 2018). In addition, the redesigning of training processes according to changes in the market and internal work environments is also expensive and lengthy, which also creates challenges in facilitating training practices on a regular basis (Erickson, 2008; Tafti et al., 2017). 


\section{Macrothink}

International Journal of Human Resource Studies

ISSN 2162-3058

2018, Vol. 8, No. 4

Furthermore, organisational or managerial failures to recognise talented employees for proper succession planning is also identified as a challenge for TM practices, therefore awareness regarding talented employees and their significance should be improved (Guthridge et al., 2008; Rioux et al., 2009; Bloom \& Reenen, 2010; Schuler, Jackson, \& Tarique, 2011; and Collings et al., 2018).

Furthermore, TM, similarly to HRM, has to ensure that all the actions for its implementation within the organisation reflects the government regulations, union expectations, corporate values and cultural norms (Collings, 2014; Khilji et al., 2015; and Tafti et al., 2017). These also create substantial challenges for the organisations to apply and practice talent management. On the other hand, the attitude and acceptance of the employees also has an impact on the establishment of TM within the organisation (Anand \& Sharma, 2017; Collings et al., 2018). Many employees and managers are not aware of the benefits that TM can create nor the challenges in implementing talent management practices (Sonnenberg, van Zijderveld, \& Brinks, 2014; Sharma, 2015; Thunnissen, 2016; Tafti et al., 2017; Starbuck, 2017; and Collings et al., 2018).

\subsection{Talent Management Model}

In the previous literature, we found many TM models which have been prepared and proposed, however the elements of the TM can be categorised into five areas that have been accommodated in the following model:

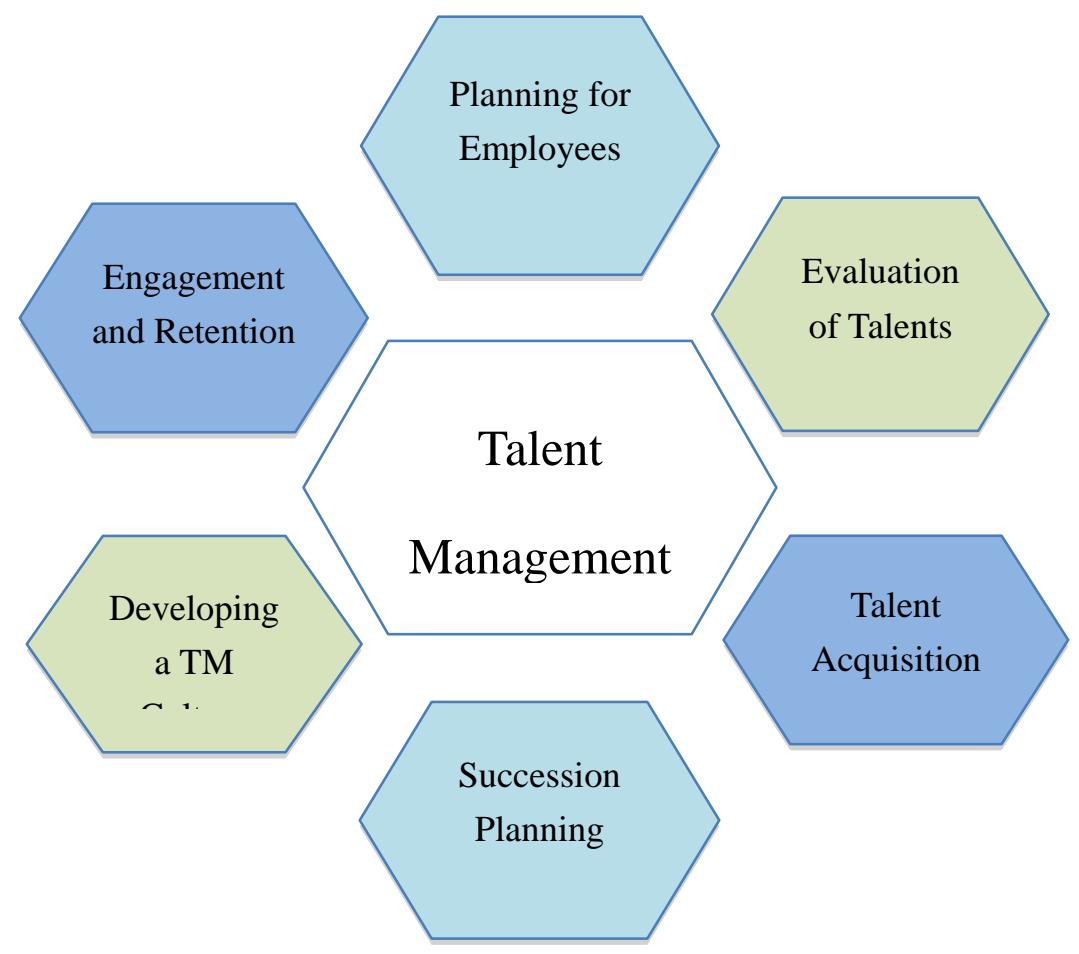

Figure 1. Talent Management Model

Source: Created by Research 


\section{Methodology}

The researchers chose a qualitative approach for this exploratory study using ten semi-structured interviews including seven managers from successful companies and three scholars from renowned universities in Bangladesh. All the participants selected were based on the purposive convenience sampling method, since they are very busy, high profile personnel in their respective fields (Creswell \& Creswell, 2017). During the interviews, detailed notes were taken but no recording systems were used because of the unwillingness of the respondents. Moreover, to ensure anonymity, participants' names have not been disclosed in the study, however, they are marked as number R1, R2, R3, R4, R5, R6, R7, R8, R9 and R10. Table 1 presents the demographic profile of the respondents of this study.

Table 1. Demographic Profile of the Respondents

\begin{tabular}{c|c|c|c|c|c}
\hline Respondents & $\begin{array}{c}\text { Marital } \\
\text { status }\end{array}$ & Position & Age & $\begin{array}{c}\text { Educational } \\
\text { Qualification }\end{array}$ & $\begin{array}{c}\text { Work } \\
\text { Experience }\end{array}$ \\
\hline R1 & Married & Manager & 44 & MBA & 16 \\
\hline R2 & Married & $\begin{array}{c}\text { Board of } \\
\text { Director }\end{array}$ & 40 & Masters & 13 \\
\hline R3 & Married & Manager & 49 & MBA & 22 \\
\hline R4 & Married & Manager & 46 & Masters & 19 \\
\hline R5 & Married & Manager & 42 & Masters & 13 \\
\hline R6 & Married & Manager & 47 & MBA & 17 \\
\hline R7 & Married & Manager & 45 & Masters & 16 \\
\hline R8 & Married & Professor & 51 & PhD & 22 \\
\hline R9 & Married & Professor & 46 & PhD & 20 \\
\hline R10 & Married & $\begin{array}{l}\text { Associate } \\
\text { Professor }\end{array}$ & 33 & PhD & 15 \\
\hline
\end{tabular}

Every interview lasted approximately thirty minutes. The interviews were conducted in English, since all the participants could competently speak and understand English. The collected data from the respondents was analysed through the use of inductive content analysis (thematic analysis = identify main themes, categories and contents).

\section{Results and Discussion}

Based on the transcripts prepared from the interviews, we determined some themes which have been identified by the respondents regarding talent management challenges within Bangladeshi private organisations. Thus, the details of the themes have been outlined in Table 2.

Table 2. Identified Challenges for Talent Management in Bangladesh

\begin{tabular}{c|c|c|c|c|c}
\hline Expenditure & Awareness & $\begin{array}{c}\text { Government } \\
\text { Support }\end{array}$ & Leadership & $\begin{array}{c}\text { Skilled } \\
\text { Trainer }\end{array}$ & $\begin{array}{c}\text { Employee } \\
\text { Turnover }\end{array}$ \\
\hline $8 / 10$ & $7 / 10$ & $10 / 10$ & $4 / 10$ & $6 / 10$ & $3 / 10$ \\
\hline
\end{tabular}

According to the analysis of the data, four main themes emerged from our research which were the most stated challenges experienced by the respondents and are common areas of the study:

1. Government support 
2. Awareness

3. Expenditure and

4. Skilled Trainer.

\section{Government Support}

All ten of the respondents opined that, "lack of government support in the case of TM development is one of the biggest barriers or challenges for Bangladeshi companies".

All of the participants opined that the present government could take examples from developed countries where TM is practiced with great importance. This is evident from the statement of R1, R2, and R3. "There are some governmental agencies or authorities in developed countries, especially in the UK, USA, Australia, France and Spain, to nurture talents of the organisations. Therefore, there are regular training sessions held by these government organisations that contribute to the greater development of the total workforce regardless of the particular industry or sector".

All of the participants insisted that the results from government initiatives for TM practices in the developed nations were evident from their statements. As a result, they have been able to develop their workforces with the respective competencies and skills. Thus, both the employees and organisational performances have been improved. R5 added that, "the Government of Bangladesh has been successful in the case of digitalisation, therefore, if TM is taken as the governmental initiative, all the workforces, especially low performing employees and even unemployed people, will benefit along with the organisations." R7 and R10 added, "a talented employee can contribute greater than others, therefore, developing employees is not only the organisation's responsibility but also a government responsibility."

\section{Awareness}

Seven out of the ten respondents opined, "lack of awareness regarding the benefits of TM has been one of the greater challenges for the organisations to apply TM practices, such as regular training and organised hiring."

$\mathrm{R} 1$ and R3 opined simultaneously that, "some employees do not like to participate in frequent training and development programs organised by Bangladeshi organisations."

R8, R9 and R10 opined that, "higher educational institutions in our country have also lacked TM related courses that can also be a reason for the lack of awareness regarding TM among graduates." R10 opined that, "there are Human Resource Management (HRM) courses in the business or management faculties in universities or colleges, however, there is no separate courses specifically relating to TM." This is also supported by R8 and R9 and they added that, "TM is taught in a very narrow way that is not sufficient to increase awareness of the graduates."

R4 and R6 added that, "most of the managers in our private organisations, as well as owners, have a lack of knowledge regarding the role of TM for the organisations in the case of attracting and retaining talented employees, but these managers think that HRM is effective 
for the talent management in their organisations. As a result, the TM practices cannot be applied successfully in an organisational context in the Bangladeshi private sector."

\section{Expenditure}

Eight out of the ten respondents opined that, "practicing TM approaches in the organisation is expensive." According to R1, "talent management is very expensive especially for the new organisations. It is because TM requires accurate estimation of what functions are proper planning to execute those functions to gain desired outcome." This view is also suggested by all of the professors who participated in the study, because they find that TM is expensive because it requires technological integration and a substantial period to achieve the outcome.

In addition, R4 and R5 stated that, "the marketing environment has been changing very quickly, sometimes we do not get any clue. In such a context, if we provide training or take a long time for hiring the right employee and promote him or her in a lengthy process, the responsibilities which he or she needs to do after the training, might not be needed anymore because of the changed market environment. As a result, the company may lose a significant amount of cash from the investment in the TM." This is also acknowledged by R6.

However, R2 opined that, "employees sometimes leave the job when he or she learns the way to work or function because they become desired and competent. Here, if the employee leaves the job after taking the TM benefits, the company finally loses money, time and effort. Therefore, many companies do not like to apply TM practices in a continuous process." All these statements are acknowledged by the rest of the respondents except R10 and R3, because they believe employees will not leave the company if they are paid enough of a salary together with other benefits. Additionally, they added that the benefits from the TM are long term, therefore, the expenditure is not a challenge for many organisations who are economically solvent.

\section{Skilled Trainer}

Six out of the ten respondents opined that, "there is a lack of skilled trainers in most of the Bangladeshi private organisations". R8 and R9 opined that, "most of the managers or the other seniors in the many private companies do not have higher degrees like a PhD or DBA, therefore, they are not well-equipped to train juniors or others efficiently in most issues or working processes." By supporting this view R10 added that, "most of the companies also do not send their managers or other seniors to take part in training or TM related programs in the developed countries which is also responsible for the lack of skilled trainers in the private companies of Bangladesh." Thus, three scholars from the universities outlined lack of trainers within the organisations to have created a significant challenge to conduct TM functions or programs for the greater development of the employee and organisational performance.

R1 has outlined, "some employees do not welcome frequent training in the organisations because they find training is boring due to lack of skills of the trainer." This is also supported by $\mathrm{R} 2$ and $\mathrm{R} 4$. They have added that, "when the talent management practices are applied in the organisations, they cannot adapt because these are sometimes confusing for the 
participated employees due to a lack of clarity, consistency, and delivery." This view is also similar to R8 and R9 in that, "to save money most of the companies do not bring skilled trainers from outside of the organisations or country therefore their own seniors conduct the training even if they are not efficient enough to deliver an informative and interesting training". However, R10 added that, "the number of training institutions has been increased in Bangladesh, if they bring skilled trainers from Western Countries to train their trainers, the skilled trainers will be increased which will bring greater contribution to the TM approach in Bangladesh."

\section{Discussion and Implications}

Our research has found four main categories of challenges for TM in Bangladesh that has been reflected from respondents being: lack of government support, poor awareness, high expenditure, and few skilled trainers. However, we have also found that poor leadership and employee turnover are challenges for the TM application in Bangladeshi private organisations that are consistent with many previous research works (Islam, Jantan, Wei, Abdullah and Manirajah, 2018). Lack of government support has been identified as the most common challenge for the development of TM in Bangladesh and it is also common in many other countries. This view is supported from the results of previous empirical studies of Mtila, Barkhuizen, \& Mokgele, 2013; Barkhuizen et al., 2014; and Khilji et al., 2017 because laws and government agencies or departments create ambiguity which generates challenges for the talent management implementation. Therefore, for the greater development of talent management in the private organisations of Bangladesh the government should increase its support in this viable arena, which will contribute to the employees' individual development and the overall development of the organisation. On the other hand, poor awareness regarding the specific features and benefits of TM among employees, managers and employers has also been identified as a significant challenge for TM development.

We have also found that expenditure is another challenge for the Bangladeshi private organisations to establish TM departments consistent with many studies, which have also acknowledged that expenditure creates challenges for every company in the case of talent management. However, according to Cappelli (2008) and Festing \& Schäfer (2014), TM gives a long-term contribution to the organisation resulting in attracting new talents, efficient employees, and retaining them. Therefore, the expenditure should be considered as an investment not an entitlement (Cappelli, 2008; Stahl, 2012; Festing \& Schäfer, 2014; Bhatnagar \& Budhwar, 2018; Lee, 2018).

It has also been identified that there is a lack of skilled trainers in Bangladeshi private organisations to nurture talents, therefore, it becomes difficult for the organisations to conduct TM approaches. In this regard, the Bangladeshi government can play a significant role by sending employees to the training programmes in the Western Countries to develop their skills so that they can train managers or other respective personnel to increase skilled trainers, which is needed for a successful TM initiative in a country (Cheese, 2007; Stahl et al., 2012; Tafti et al., 2017; Khilji, et al., 2017). Moreover, the organisations should also sponsor the managers or other employees so that they can take part in different training programs to 
sharpen their training skills for greater talent management in their organisations (Cheese, 2007; Foster, 2015; and Sheehan et al., 2018). Hence, we believe that both private organisations and respective governments should come forward to train the potential trainers, especially managers and other highly experienced personnel, so that they can conduct training and sharpen talents within the companies.

\section{Conclusion}

This study has identified some key challenges that should be reviewed and acted upon in order to achieve greater organisational performance. According to the respondents of the study, if these challenges can be overcome, the number of skilled employees will be increased and overall organisational performance will be improved, which is needed to meet the increasing demand of the growing population in Bangladesh. The respective stakeholders should take the main aspects reflected from this study seriously in order to act for the greater benefit of the organisations, especially those struggling in the area of attracting and retaining talented employees. However, the integrated approach of private organisations and the government can be effective for the development of TM in Bangladesh. In addition, the respective employees in the organisations should be aware of TM and its benefits and be interested to take part in different TM related programs.

\section{Limitations of the Study and Directions for Future Research}

There are some limitations to this study. The study has also included primary data from ten respondents, however, in future research studies more respondents could be included in order to collect more information and categorise additional themes based on the collected information. Furthermore, the study has been completed based only on a private industry context; therefore, the future research could be conducted in a public industry context.

\section{References}

Al Ariss, A., Cascio, W. F., \& Paauwe, J. (2014). Talent management: Current theories and future research directions. Journal of World Business, 49(2), 173-179. https://doi.org/10.1016/j.jwb.2013.11.001

Anand, P., \& Sharma, P. C. (2017). Empirical study on the employee perception of talent management processes in Indian telecom sector. SMART Journal of Business Management Studies, 13(2), 51-60. https://doi.org/10.5958/2321-2012.2017.00014.8

Bahadir, S. C., Bharadwaj, S., \& Parzen, M. (2009). A metaanalysis of the determinants of organic sales growth. International Journal of Research in Marketing, 26(4), 263-275. https://doi.org/10.1016/j.ijresmar.2009.06.003.

Barkhuizen, N., Mogwere, P., \& Schutte, N. (2014). Talent management, work engagement and service quality orientation of support staff in a higher education institution. Mediterranean Journal of Social Sciences, 5(4), 69. http://dx.doi.org/10.5901/mjss.2014.v5n4p69. 
Bhatnagar, J., \& Budhwar, P. (2018). Macro talent management in India: A contextual analysis of the challenges, opportunities and emerging patterns. In Macro Talent Management in Emerging and Emergent Markets (pp. 105-123). Routledge.

Bloom, N., \& Reenen, J. V. (2010). Why do management practices differ across firms and countries? Journal of Economic Perspectives, 24, 203-224. Https://doi.org/10.1257/jep.24.1.203.

Brewster, C., Cerdin, J. L., \& Sharma, K. (2017). Global Talent Management in the Not-for-Profit Sector. In Competencies and (Global) Talent Management (pp. 1-24). Springer, Cham.

Cappelli, P. (2008). Talent management for the twenty-first century. Harvard business review, 86(3), 74.

Cheese, P. (2007). The talent powered organization: Strategies for globalization, talent management and high performance. Kogan Page Publishers.

Christensen, H. J., \& Rog, E. (2008). Talent management: A strategy for improving employee recruitment, retention and engagement within hospitality organizations. International Journal of Contemporary Hospitality Management, 20(7), 743-757.

Collings, D. G., Scullion, H., \& Caligiuri, P. (2018). Global talent management. Routledge.

Collings, D.A. (2014), Integrating global mobility and global talent management: exploring the challenges and strategic opportunities, Journal of World Business, 49(2), 253-61. https://doi.org/10.1016/j.jwb.2013.11.009.

Creswell, J. W., \& Creswell, J. D. (2017). Research design: Qualitative, quantitative, and mixed methods approaches. Sage publications.

De Gieter, S., \& Hofmans, J. (2015). How reward satisfaction affects employees' turnover intentions and performance: an individual differences approach. Human Resource Management Journal, 25(2), 200-216. https://doi.org/10.1111/1748-8583.12072.

Euro Monitor (2018) Asia Pacific: Regional Profile. [Online] Available: https://www.euromonitor.com/asia-pacific-regional-profile/report. (June 01, 2018).

Festing, M., \& Schäfer, L. (2014). Generational challenges to talent management: A framework for talent retention based on the psychological-contract perspective. Journal of World Business, 49(2), 262-271. https://doi.org/10.1016/j.jwb.2013.11.010.

Foster, C. L. (2015). Managing the flow of talent through organizations-a boundary-less model. Development and learning in organizations: an international journal, 29(1), 15-19. https://doi.org/10.1108/DLO-06-2014-0045.

Glaister, A. J., Karacay, G., Demirbag, M., \& Tatoglu, E. (2018). HRM and performance-The role of talent management as a transmission mechanism in an emerging market context. Human Resource Management Journal, 28(1), 148-166. https://doi.org/10.1111/1748-8583.12170. 


\section{Macrothink}

International Journal of Human Resource Studies

ISSN 2162-3058

2018, Vol. 8, No. 4

Guthridge, M., Komm, A. B., \& Lawson, E. (2008). Making talent a strategic priority, The Mckinsey Quarterly.

Haq, N. (2018) Bangladesh's Garment Industry Boom Leaving Workers Behind. [Online] Available:

http://www.ipsnews.net/2018/02/bangladeshs-garment-industry-boom-leaving-workers-behin d/. (June 02, 2018).

Heinen, J. S., \& O'Neill, C. (2004). Managing talent to maximize performance. Employment Relations Today, 31(2), 67-82.

Heinrich, E. (2017). Overcoming Regional Retention Issues: How Some Michigan Organizations Use CSR to Attract and Engage Top Talent. In Corporate Social Responsibility, Sustainability, and Ethical Public Relations: Strengthening Synergies with Human Resources (pp. 89-122). Emerald Publishing Limited.

Iles, P., Chuai, X., \& Preece, D. (2010). Talent management and HRM in multinational companies in Beijing: Definitions, differences and drivers. Journal of World Business, 45(2), 179-189. https://doi.org/10.1016/j.jwb.2009.09.014.

Islam, M. A. et al, (2018). Factors Influencing Female Progression in Leadership Positions in the Ready-Made Garment (RMG) Industry in Bangladesh. Journal of International Business and Management, 1(1), 1-13.

Kantar Worldpanel. (2018). Bangladesh [Online] Available: https://www.kantarworldpanel.com/global/Coverage/europanel/Bangladeshhttps://www.kanta rworldpanel.com/global/Coverage/europanel/Bangladesh. (June 02, 2018).

Khilji, S., Tarique, I., \& Schuler, I. R. (2015), Incorporating the macro view in global talent management, Human Resource Management Review, 25(3), 236-48.

Lee, G. J. (2018). Talent measurement: A holistic model and routes forward. SA Journal of Human Resource Management, 16(11). https://doi.org/10.4102/sajhrm.v16i0.990

Liamas, C. (2018). The importance of talent management and why companies should invest in it. [Online] Available: https://www.humanresourcesonline.net/the-importance-of-talent-management-and-why-comp anies-should-invest-in-it/. (June 03, 2018).

Mtila, J., Barkhuizen, E. N., \& Mokgele, R. (2013). Exploring the Application of Talent Management Practices in a Local Government Institution. In S.M. Lee \& G. Roodt (Eds.), 30th Pan Pacific Conference, Johannesburg, South Africa (pp. 66-68).

Nilsson, S., \& Ellström, P. E. (2012). Employability and talent management: challenges for HRD practices. European Journal of Training and Development, 36(1), 26-45. https://doi.org/10.1108/03090591211192610.

Oladapo, V. (2014). The impact of talent management on retention. Journal of business studies quarterly, 5(3), 19. 


\section{Mll Macrothink}

International Journal of Human Resource Studies

ISSN 2162-3058

2018, Vol. 8, No. 4

Rioux, S. M., Bernthal, P. R., \& Wellins, R. S. (2009). The globalization of human resource practices. Special report for development dimensions international. Bridgeville, PA: DDI.

Schuler, R. S., Jackson, S. E., \& Tarique, I. (2011). Global talent management and global talent challenges: Strategic opportunities for IHRM. Journal of World Business, 46(4), 506-516. https://doi.org/10.1016/j.jwb.2010.10.011.

Sharma, E. (2015). Employee perception towards talent development practices in telecom sector. European Journal of Research in Social Sciences, 3(1).

Sheehan, M., Grant, K., \& Garavan, T. (2018). Strategic talent management: A macro and micro analysis of current issues in hospitality and tourism. Worldwide Hospitality and Tourism Themes, 10(1), 28-41. https://doi.org/10.1108/WHATT-10-2017-0062.

Sidani, Y., \& Al Ariss, A. (2014). Institutional and corporate drivers of global talent management: Evidence from the Arab Gulf region. Journal of World Business, 49(2), 215-224. https://doi.org/10.1016/j.jwb.2013.11.005.

Sonnenberg, M., van Zijderveld, V., \& Brinks, M. (2014). The role of talent-perception incongruence in effective talent management. Journal of World Business, 49(2), 272-280. https://doi.org/10.1016/j.jwb.2013.11.011.

Stahl, G., Björkman, I., Farndale, E., Morris, S. S., Paauwe, J., Stiles, P., ... \& Wright, P. (2012). Six principles of effective global talent management. Sloan Management Review, 53(2), 25-42.

Starbuck, W. H. (2017). Organizational learning and unlearning. The Learning Organization, 24(1), 30-38. https://doi.org/10.1108/TLO-11-2016-0073

Tafti, M. M., Mahmoudsalehi, M., \& Amiri, M. (2017). Critical success factors, challenges and obstacles in talent management. Industrial and Commercial Training, 49(1), 15-21. https://doi.org/10.1108/ICT-05-2016-0036

Thunnissen, M. (2016). Talent management: For what, how and how well? An empirical exploration of talent management in practice. Employee Relations, 38(1), 57-72. https://doi.org/10.1108/ER-08-2015-0159.

Thunnissen, M., Boselie, P., \& Fruytier, B. (2013). Talent management and the relevance of context: Towards a pluralistic approach. Human Resource Management Review, 23(4), 326-336. https://doi.org/10.1016/j.hrmr.2013.05.004.

Trade Economics (2018) Bangladesh Foreign Direct Investment - Forecast [Online] Available: https://tradingeconomics.com/bangladesh/foreign-direct-investment/forecast. (June 03, 2018).

Vaiman, V., Scullion, H., \& Collings, D. (2012). Talent Management Decision Making. Management Decision, 50(5), 925-941. https://doi.org/10.1108/00251741211227663.

Vaiman, V., Sparrow, P., Schuler, R., \& Collings, D. G. (Eds.). (2018). Macro Talent Management: A Global Perspective on Managing Talent in Developed Markets. Routledge. 


\section{Macrothink}

International Journal of Human Resource Studies

ISSN 2162-3058 2018, Vol. 8, No. 4

Wilder, K. M., Collier, J. E., \& Barnes, D. C. (2014). Tailoring to customers' needs: Understanding how to promote an adaptive service experience with frontline employees. Journal of Service Research, 17(4), 446-459. https://doi.org/10.1177/1094670514530043.

\section{Copyright Disclaimer}

Copyright for this article is retained by the author(s), with first publication rights granted to the journal.

This is an open-access article distributed under the terms and conditions of the Creative Commons Attribution license (http://creativecommons.org/licenses/by/4.0/). 